\title{
sciendo
}

UDK: 336.711(094.5)

DOI: $10.2478 /$ jcbtp-2021-0001

Journal of Central Banking Theory and Practice, 2021, 1, pp. 5-38

Received: 06 March 2019; accepted: 27 June 2019

Bryane Michael ${ }^{*}$, Svitlana Osaulenko **

\section{TOWARD A NEW COMPARATIVE PUBLIC LAW OF CENTRAL BANK LEGISLATION: Designing Legislative Mandates for Central Bank Private Securities Assets Purchases and Nominal GDP Targeting}

\begin{abstract}
What role could unconventional monetary policy - and particularly unconventional policies like private asset purchases under a quantitative easing or lender of last resort scheme - play in influencing economic growth directly? A wide literature in economics explores the pros and cons of using these policies. However, most studies also point to the uncertain and antagonistic legal basis for such purchases. In this paper, we show how the statutory mandate for nominal GDP targeting could best put in place the legal foundations for such asset purchases. We review the legislative and regulatory bases for private securities purchases made by central banks in a sample of countries. We discuss - if legislators and policymakers wanted to - how they might introduce clearer mandates to make such purchases into their public law. We finally show how legal authorizations for GDP targeting might (and probably should) provide for such authorisations. Our discussion sheds light on the fascinating and almost completely ignored area of public law, namely central bank law.
\end{abstract}

Keywords: central bank law, central bank private securities purchases, public (monetary) law, GDP targeting.

JEL Codes: E58, E42, K23, O23.
${ }^{*}$ University of Oxford, Oxford, United Kingdom

E-mail:

bryane.michael@eueconomics.org

${ }^{* *}$ Odessa Academy of Law,

Odessa, Ukraine

E-mail:

osaulenko_sv@ukr.net 
Disclaimer: The material in this paper does not represent formal advice to any institution, and does not reflect any of the positions of any of the institutions to which the authors affiliate. The co-authors have worked on different parts of the paper - and thus may not necessarily agree with all the contents. In this way, we do not need to negotiate or censor particular results appearing in the marketplace of ideas.

Acknowledgements: Special thanks to the Hong Kong Theme-Based Research Grants Council Scheme for partial funding for this paper. All errors are our own. We extend particular thanks to the Max Planck Institute for Comparative Public Law and International Law (MPIL) for their assistance during one of our stays with them in 2017.

\section{Introduction}

During the global financial crisis of 2007-9 (and beyond), many countries' central banks bought large amounts of private sector stocks, bonds, securitized instruments and other securities. ${ }^{1}$ By buying these kinds of private sector securities, these central banks tried to make markets for all securities more liquid and restore investors' confidence. Social scientists of all types will debate the effects of these purchases for years to come. ${ }^{2}$ Yet, policymakers and the public have debated - and continue to debate - the legality of these purchases. ${ }^{3}$ Conventional thinking goes that central banks usually add liquidity to the investment markets by buying and selling 'safe' government securities - not risky private sector ones. ${ }^{4}$ Following this thinking, most countries' central bank law do not forbid private sector securities purchases - but also do not encourage such 'unconventional monetary policy' (Borio and Zabai, 2016).

As more policymakers accepted unconventional monetary policy measures like these, public discourse dared to even revisit whether central banks can - and

1 Literally hundreds of papers address these issues. However, Paries and Kuhl (2016) describe the actual, as opposed to optimal, central bank purchases made during the 2007-8 financial crisis. Weale and Wieladek (2014) describe some of the macroeconomic effects of these purchases. Joyce et al. (2012) describe the unconventional monetary policies many of these central banks engaged in during the crisis.

2 Gambacorta and his co-authors (2014) describe the debates around the use of unconventional monetary policies.

3 Emerson (2010) provides a fascinating description of the Fed's legal machinations aimed at buying failing companies during the financial crisis.

4 Such a philosophy underlines these institutions' role as a lender of last resort - something we do not discuss in this article. Interested readers should see Le Maux and Scialom (2013) for a description of lender of last resort in various jurisdictions. Tucker (2014) describes the broader principles underlying the appropriateness and conditions of central banks' lending in times of extreme economic crisis. 
should - try to directly influence economic growth as well as prices. Analysts like Woodford (2012) noted that giving the US Federal Reserve Bank (the US's central bank) the power to buy assets would increase the credibility of its nominal GDP targeting -- and thus changes expectations (85). As Csermely and Toth (2013) note, such targeting asks the central bank to focus on achieving a certain level of economic growth, taking into account any price increases that may eat away at the value of such growth. The central bank could thus act like a 'helicopter' - dropping money onto investors who need it, "mop up" the demand for assets which has temporarily fallen ...and best of all, without increasing public sector debt. ${ }^{5}$

In this paper, we ask - what legislative drafting method would best give a central bank the legal (legislative and even sometimes constitutional) mandate to engage in such private sector securities purchases? The first section of our paper reviews the legislative provisions in place in a sample of countries (as we cannot analyse all 190 central banks' laws). We show the range of general permissiveness in central bank laws for such purchases - ranging from agnostic to repulsive (prohibiting such purchases). The second section looks at such permissiveness specifically if/when the central bank needs to save the economy (by acting as an investor/lender of last resort). Naturally, central banks would not make these purchases for fun - but for real outcomes tied to their prime objectives. Most laws allow these banks to make these purchases under dire circumstances. Yet, what constitutes such a dire circumstance? And if economists are starting to rethink the conventional wisdom about unconventional monetary policy, what kind of laws would best help these banks achieve these prime objectives? The third section discusses the legal mandate to maximize nominal GDP (or economic growth minus inflation) as the simplest and best way of setting these objectives into law (and authorizing central banks to achieve them). We discuss six strategies lawmakers could pursue - depending on the law already on the books. The final section concludes.

The paper makes several contributions to the legal literature. First, and foremost, we hope to put the study of central bank law back on the map for students of public law and even administrative law. If academics and practitioners have increasingly analysed laws regulating the executive, parliament and judiciary - few have looked at the jurisprudential bases of central bank law. Second, we introduce the topic to the field of comparative and/or international law - analysing these laws

\footnotetext{
5 Most analysts of such helicopter funding - like Bossone and his colleagues (2014) -- see going around increases in government debt as one of the big advantages of such financing (in addition to keeping interest rates low).
} 
across countries as lawyers, rather than as economists. While central bank and monetary policy remain the purview of economists, the statutory (and even constitutional) basis upon which states conduct such policies remains untheorized. We introduce much-needed empirical findings, by providing a taxonomy of the types of central banks laws - and the way they deal with the central bank's role in fostering economic growth. By talking about the legal mechanics of nominal GDP targeting, we hope to add a new dimension to an area of economics that even economists still have not deeply discussed since the times of Milton Friedman.

Our paper comes with a very large caveat, which will bother many readers. We assume policymakers want to allow such purchases, as economically desirable. As such, we do not discuss whether these private sector securities purchases promote investment and/or GDP growth. ${ }^{6}$ Naturally, many countries would benefit from central banks' on-going intervention in their capital/securities markets... and others not. Yet, as jurists, we want to know what legal drafting techniques might best put in place an authorization for private securities purchases, in case a future state-of-the-world might make such purchases economically beneficial. We thus also assume the reader has some knowledge of central bank finance and particularly the ways and reasons why these institutions buy and sell securities. We similarly do not provide background discussions about nominal GDP targeting, as we discuss the issue in another paper.

\section{Do Central Bank Statutory Objectives Allow Them To Invest at Home?}

Many policymakers think that central banks have the legal (or at least operational) mandate to only buy government securities. ${ }^{7}$ Perceived restrictions on private asset purchases stem from a historical accident - rather than a conscious design (Posner, 2016). As Broaddus and Goodfriend (2000) have documented, historical tradition led to the US Federal Reserve Bank to adopt a "Treasuries only" policy. Yet, the Federal Reserve Act of 1913 allowed (and allows) the Fed to buy private sector assets in its now much-debated article 13 (in sub-sections 2 and 3). Subsequent rulemaking - some in reaction to the US Fed's private asset purchases dur-

\footnotetext{
${ }^{6}$ Fawley and Juvenal (2012) look at the lessons learned from quantitative easing. Gagnon and his colleagues look at the effectiveness of the US central bank's large-scale asset purchases (2010, Table 5b).

7 Readers with doubts should see Shill (2015).
} 
ing the global economic crisis of 2007-8 -- has sought to hem in such powers. ${ }^{8} \mathrm{We}$ do not analyse the US law or the best rules for such purchases, given our focus on developing countries. Instead, we wish to correct a misperception held by central banks worldwide due to a US policy based more on history than law. ${ }^{9}$ Even in the US, the debate about the extent to which its central bank should become a funder of last resort for private enterprise still remains unsettled. ${ }^{10}$

Following this conventional wisdom, few countries' central banking laws provide for private asset purchases. Figure 1 -- using data from the IMF (2016) and Khan (2017) -- shows the number of central bank laws with various objectives; price stability, growth as a subsidiary objective, and growth as equal to price stability. According to these data, most central bank laws seem reasonably sanguine about central bank policies aimed at promoting output growth and thus investment. Yet, our own replication of their work shows a different picture. Most countries' central banking laws remain antagonistic to central bank purchases of private sector securities. Figure 2 compares central bank laws across countries according to whether they have output-investment related objectives and provide for central banks to buy private sector securities. Only about $25 \%$ of jurisdictions in our random sample of 25 countries had central banking laws which included economic growth and/or development as a goal. The same percent remain completely hostile to such purchases - completely ignoring output growth as an objective and explicitly forbidding private securities purchases. Thus, private asset purchases depend on more than simply politics. ${ }^{11}$ Developing countries' central banking laws in general prohibit them from using non-conventional private sector asset purchases either during crises or in normal times.

8 For an overview and critique of the Fed's private asset purchase powers, see Alexander Mehra, Legal Authority in Unusual and Exigent Circumstances: The Federal Reserve and the Financial Crisis, University of Pennsylvania Journal of Business Law 13(1), 2010, available at: https://www. law.upenn.edu/journals/jbl/articles/volume13/issue1/Mehra13U.Pa.J.Bus.L.221(2010).pdf.

9 Labonte (2016) provides a fascinating history of such the restrictions on US emergency lending. Fettig (2002) provides a detailed description of the Fed's own lending to businesses.

${ }^{10}$ As Johnson (2016) notes, the moral hazard issues involved provide enough reason for such controversy. For a view of such lending as encouraging moral hazard,

${ }^{11}$ Saravelos, Brehon, and Winkler (2016), after reviewing only a few jurisdictions (UK, US, EU, Japan) on monetary financing flatulently note that "taking it all together, we conclude that historical experience and institutional flexibility provides plenty of flexibility for monetary financing. Ultimately, it is a question of political desirability rather than technical or legal constraints." They do not analyse politics at all in their paper. 
Figure 1: More than Half of Central Bank Statutes Hostile-ish to Private Asset Purchases

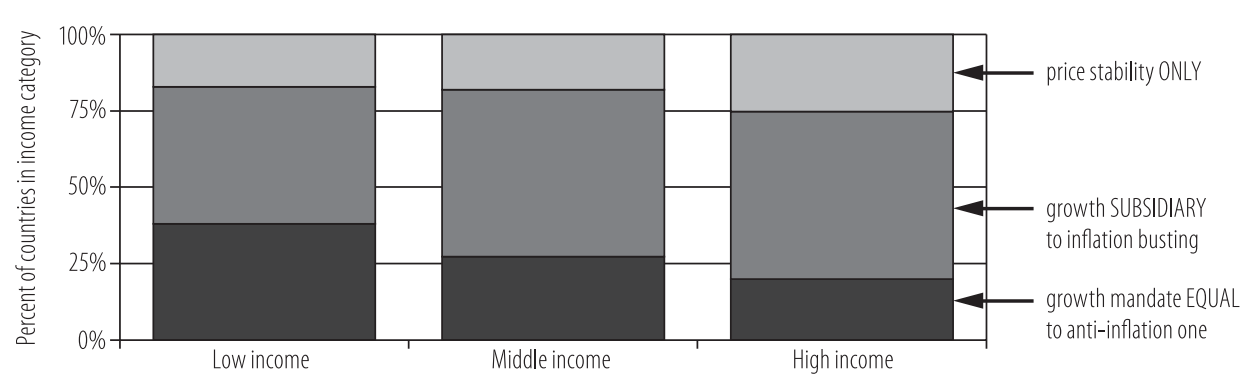

The figure shows the proportion of jurisdictions whose central bank statutes' objectives place price stability first, give macroeconomic growth an equal (unspecified ranking) role or subordinate/subsidiary role. We rescaled the original figure to find proportions, as a percent of each income group (ie conditional proportions). Our own sample of central banks finds significant differences with these data.

Source: IMF Central Bank Legislation Database (2016) at Chart 2.

Figure 2: Most Countries Antagonistic Toward Central Bank Private Securities Purchases

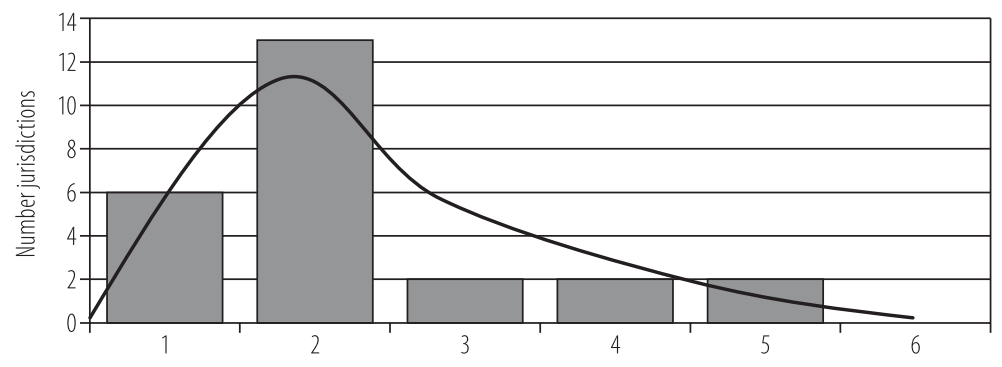

\begin{tabular}{|c|c|c|}
\hline Rating & Meaning & Countries \\
\hline 1 & $\begin{array}{l}\text { Investment not mentioned and private purchases } \\
\text { explicitly forbidden }\end{array}$ & Poland, Mozambique, Ecuador, Malaysia, Guatemala, Philippines \\
\hline 2 & $\begin{array}{l}\text { Investment not as objective and private } \\
\text { purchases ambiguous }\end{array}$ & $\begin{array}{l}\text { Japan, Malta, Uganda, Mauritania, Oman, Switzerland, Burundi, Poland, } \\
\text { Cameroon, Madagascar, Switzerland, Turkmenistan, Myanmar }\end{array}$ \\
\hline 3 & Investment as objective but private purchases forbidden & Jamaica and Argentina \\
\hline 4 & $\begin{array}{l}\text { Investment as objective somewhere and ambiguous } \\
\text { about private purchases }\end{array}$ & Haiti and Iraq \\
\hline 5 & $\begin{array}{l}\text { Investment as subsidiary objective and private purchases } \\
\text { explicitly allowed }\end{array}$ & $\begin{array}{l}\text { Costa Rica } \\
\text { St. Vincent }\end{array}$ \\
\hline 6 & $\begin{array}{l}\text { Investment as main (primus entre parus) objective and } \\
\text { private purchases explicitly allowed }\end{array}$ & None \\
\hline
\end{tabular}

The figure shows the results of a random sample of 25 countries' central bank laws. We assessed whether these laws had output/development related objectives and whether they allowed, forbad or left unclear the central bank's authority to buy private sector securities/assets. 
Of the countries which allow the central bank to hold private sector assets, many holdings arise as from collateral that the central bank takes from local banks. ${ }^{12}$ As discussed previously, central banks - including the ECB - may discount, rediscount, purchase for repurchase and otherwise accept as collateral private sector securities. Most economists agree that - no matter the central bank objectives in place -- the optimal composition of central bank collateral may consist in part in private sector securities (if only to off-load later). ${ }^{13}$ As Nyborg (2015) describes, these decisions affect (if not distort) asset prices, allocation decisions and market risks/returns. Less than $40 \%$ of central banks allow private securities on their balance sheets. Why should banks take private sector collateral when they suffer from their limited collateral values in times of crisis? Figure 3 shows the percent of central banks holding each type of asset. Covered bonds represent a useful asset class - though low equity holdings represent something more worrying. These rules forget that such investments supposedly represent real assets sitting somewhere in a real economy.

Figure 3: Are Private Asset Purchase Restrictions on Central Bank Collateral Really Optimal for More than $40 \%$ of Countries?

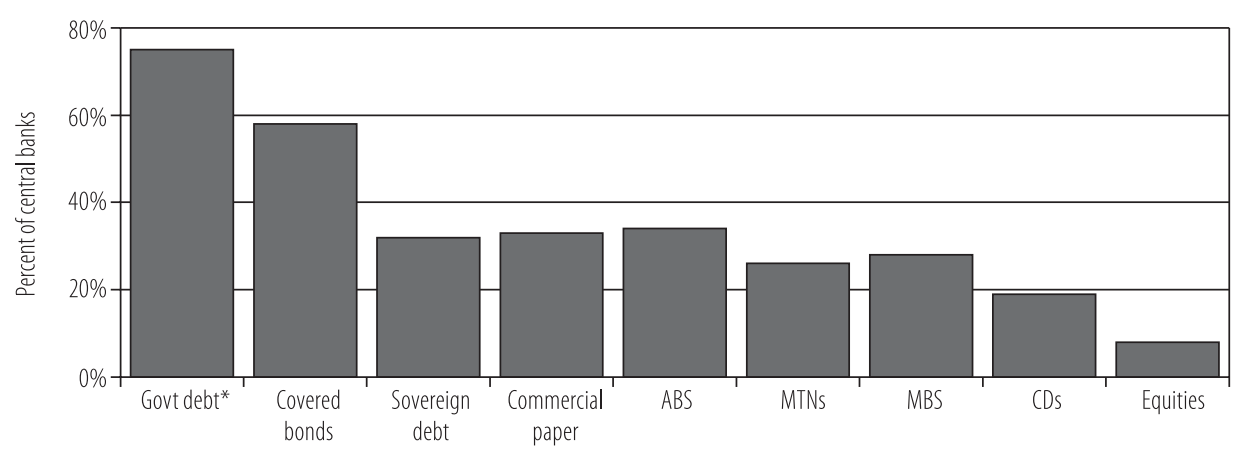

The figure shows the proportion of central banks allowing each of these types of collateral on their balance sheets. See original source for definitions of these asset classes, countries responding their survey, etc.

* Such US dollar and euro denominated debt covers bonds, bills and so forth.

Source: Hobson (2016).

${ }^{12}$ Such holdings namely come about as the result of discounting, rediscounting or as collateral in the case of default and repurchase agreements. Discounting refers to the central bank's nominal holdings of these securities in exchange for cash which the bank would later sell for a reasonable return equal to roughly the prevailing market interest rate when banks buy the assets back.

${ }^{13}$ To keep our paper relatively focused, we do not review the literature on central bank collateral. Lane (2015) provides a deeper discussion on central bank collateral. 
Central bank laws do not give the central bank the explicit obligation to use monetary to boost economic growth. Yet, different countries define central bank objectives as instruments which hopefully would promote investment and increase economic growth. ${ }^{14}$ Figure 4 shows the five major categories of central bank law objectives we found in our random sample of central bank laws. We provide specific examples from each category in the text below. Yet, in all these laws, we observe one constant. No central bank law seems to provide clear and definitive authority for the central bank to purchase private sector assets/securities in the interest of either conventional or unconventional monetary policy.

Figure 4: Examples of Pro-Output Objectives in Central Bank Laws

\begin{tabular}{lc}
\hline \multicolumn{1}{c}{ Investment via ... } & Example Countries \\
\hline Stable banking system & Oman, Jamaica (credit), Japan. \\
\hline Solid macroeconomic environment & Guatemala \\
\hline supporting government policies & Ecuador, Poland, Argentina, Madagascar, \\
\hline direct intervention & Costa Rica, Eastern Caribbean Central Bank, \\
exhortations to promote the national interest & Bank of Central African States, Malta, \\
\hline
\end{tabular}

First, central bank laws seek to promote output growth by maintaining a wellfunctioning banking system. Oman's central bank law for example clearly places the onus of growth and development on, "the development of banking institutions which will...contribute to economic, industrial, and financial growth" (art. 1(a)). ${ }^{15}$ The Law authorises the Board of Governors with discretion to decide on assets. Most of these assets though should consist of loan and loan-like instruments held by banks, government guaranteed debts or equities, securities/debts from foreign governments and international organisations (ibid, art. 28).

Haiti's central bank law defines numerous, albeit oblique, requirements to foster output growth and/or development as a central bank objective. ${ }^{16}$ The Bank must "encourage the most complete and effective development and utilisation of the country's productive resources" and "facilitate the expanse of domestic and

\footnotetext{
${ }^{14}$ As Asso, Kahn, and Leeson (2010) describe, maximising output growth and stability never lies far from central banker minds, as well as the minimisation of price growth and instability.

${ }^{15}$ Oman Banking Law, at article 1(a), available at: http://www.parliament.am/library/kentronakan\%20bank/oman.pdf.

${ }^{16}$ Law of the 17th August 1979 Creating the Bank of the Republic of Haiti Hereafter Designated $\mathrm{BRH}, \mathrm{m}$ at $2.2,2.6$ and 2.3 respectively, available at: https://www.haiti-now. org/wp-content/uploads/2013/01/L\%C3\%A9gislation-des-banques-et-des-institutions-financi\%C3\%A8res-1985.pdf.
} 
international trade with regard for instituting and maintaining an elevated level of employment and real revenue." by adopting methods of payment and credit policies to allocate money "to legitimate needs of the Haitian economy, and in particular, the growth of national production" (at arts. 2.2, 2.6 and 2.3 respectively). The law gives the Haitian central bank powers to even "...in the manner of financial institutions' credit operations, vesting and investment determine: a) the objectives of lending...d) the individual or collective limits of different categories of lending operation, placements and investments."

Jamaica's central bank law imposes similar objectives to "influence the volume and conditions of the supply of credit so as to promote the fullest expansion in production, trade and employment" (art. 5).$^{17}$ Like most banks, the Jamaican central bank may hold -- gold, foreign currencies, government securities and securities from foreign/international financial institutions (art. 21). Yet, the law expressly forbids the "purchase the shares of any other bank or of any other company or grant loans on the security of any shares in any bank or company" (art. 24(b)). Thus, the law sees private sector assets on the central bank's balance sheet as a temporary mistake - collateral which the bank must offload quickly rather than a monetary policy tool.

Japan's experience possibly foreshadows those of other markets. Japan's central bank law aims at "ensuring the smooth settlement of funds among banks and other financial institutions, thereby contributing to the maintenance of stability of the financial system" (art. 1). ${ }^{18}$ The law repeats this objective in the next article "aimed at achieving price stability, thereby contributing to the sound development of the national economy" (art. 2). Certainly nothing foreshadows the eventual private sector asset build-up on the Bank of Japan's balance sheet. Nothing in Japan's central bank law either allows nor prevents the Bank from buying and holding private securities as part of its "regular business" (article 33) or "prohibition of other business" (section 43). Yet, the article allows the Minister of Finance and the Prime Minister to authorise the Bank to conduct other business in "the case where such business is necessary to achieve the Bank's purpose specified in this Act." Nothing in the Bank's objectives suggests that acquiring private assets represents a way of promoting price stability. Yet, to possibly foreshadow other countries, despite these weak legal rules, Japan's central bank has embarked on large-scale private asset purchases.

\footnotetext{
${ }^{17}$ The Bank of Jamaica Act, 1960, at article 5, available at: http://boj.org.jm/pdf/BANK OF JAMAICA ACT.pdf.

${ }^{18}$ Bank of Japan Act (Act No. 89 of June 18, 1997) at article 1, available at: https://www.boj.or.jp/ en/about/outline/data/foboj12.pdf.
} 
A second way central bank laws target economic growth by creating a stable macroeconomic environment. Guatemala's central bank law similarly describes the Bank's contribution to the broader macroeconomic and financial environment rather than direct participation - with "the fundamental objective to contribute to the creation and maintenance of the most favourable conditions for the orderly development of the national economy...[through] monetary, foreign exchange and credit conditions that promote the stability in price levels in general" (art. 3). ${ }^{19}$ As one of the stricter laws, Guatemala's law prohibits the Bank from "giving loans to natural or legal persons, except to banks in the banking system..." as well as the purchase shares, except those issued by international financial organisations in which the Bank participates as a member" or "participate directly or indirectly in any commercial, agricultural, industrial or any other class of enterprise" (arts $71 \mathrm{~b}, 71(\mathrm{e})$ and (g) respectively). The law thus allows private asset purchases to play no role in monetary policy.

The third way central bank laws target economic growth by supporting government's economic policies. For example, Ecuador's constitution makes plain that output promotion, as a policy of the Government, can serve as an objective, as "the formation of monetary, credit, foreign exchange and financial policies is the exclusive remit of the Executive and is conducted through the Central Bank" (art. 303). ${ }^{20}$ Similarly, Ecuador's constitution provides the diffuse competencies for the central bank to place output growth as a key objective, to "orient excess liquidity toward required investments in national development" and influence interest rates toward the "finance of productive activities" (art. 302). Yet, the law hinders Ecuador's central bank's ability to make these investments by prohibiting that it "acquire or guarantee company shares of any class and to participate directly or indirectly in companies or corporations, except in shares or equity participation in international monetary institutions" (art. 84). ${ }^{21}$

Polish law deals with growth in a similar way. While price stability comprises the Bank's prime directive, the Bank must work in "supporting the economic policy of the Government, insofar as this does not constrain the pursuit of [price stability]" (art. 3.1). ${ }^{22}$ Unlike in the previous case though, the Polish law forbids the Bank from holding shares "except those providing services solely to financial

${ }^{19}$ Decree No. 16-2002 Congress of the Republic of Guatemala, at article 3, available at: http:// www.banguat.gob.gt/leyes/2002/orga bg.pdf.

${ }^{20}$ Constitution of Ecuador, article 303.

${ }^{21}$ Law of Monetary Regime and State Bank, at article 84.

22 The Act on Narodowy Bank Polski of 29 August 1997, Journal of Laws of 2013 item 908, at article 3.1, available at: http://www.nbp.pl/en/aktyprawne/the act on the nbp.pdf. 
institutions and the State Treasury..." (art. 5.2). Thus, Polish law makes clear that private investment shall represent a way the bank supports government policies.

Similarly, Argentine policy subordinates its central bank to the government "within the framework of its powers and the policies set by the National Government" (charter). ${ }^{23}$ Within that framework, the law requires the Bank to "promote...monetary and financial stability, employment, and economic development with social equality" (ibid). The law allows the Bank to transact in "other financial assets" (other than government securities and foreign exchange) - thus presumably opening the door to private sector securities (art. 18.a). Yet, the law explicitly forbids the Bank to "purchase shares, except for those issued by international financial organisations" as well as "hold a direct or indirect interest in any commercial, agricultural, industrial or any other company" (ibid, sec 19 (f) and (g) respectively). Thus, like most, the law starts by forbidding such purchases, but leaves the door open to allowing such purchases in case of need.

Madagascar's central bank similarly, in a subsidiary objective, requires the Bank to "support[] the Government's general economic policy" (p.5629). ${ }^{24}$ Madagascar's central bank law does allow the Bank to intervene in capital markets by buying, selling, repurchasing, or discounting securities as well as by taking securities as collateral (ibid, art. 17). Similarly with other jurisdictions, the law allows the Bank to hold as reserves securities issued by states and financial institutions abroad - with a catch-all exception for "all other negotiable financial asset denominated in a convertible currency.," leaving the Board of Directors free to "pass resolutions related to the management of foreign exchange reserves by the Central Bank in order to assure their liquidity, security and yield" (ibid, art. 19).

The fourth way consists of directly intervening to promote growth. Costa Rica's law places the "orderly development of the Costa Rican economy" as its first subsidiary objective "to achieve full use of the Nation's productive resources, avoiding or controlling inflationary or deflationary tendencies which may arise in the monetary and credit markets" (art. 2.a). ${ }^{25}$ The Bank's Department for Economic Promotion and Development may "channel funds... for financing different eco-

${ }^{23}$ See Charter of the Central Bank of the Argentine Republic (Carta Organica), available at: http:// www.bcra.gob.ar/Pdfs/Institucional/CartaOrganica2012 i.pdf.

${ }^{24}$ Statute of the Madagascar National Bank, Law No. 2016-004 of 29 July 2016, \#3708 of the $26^{\text {th }}$ of September 2016, p.5629, available at: http://www.banque-centrale.mg/getPDF. php?id=m8 $3 \quad 7 \quad 22$.

${ }^{25}$ Organic Law of the Costa Rica Central Bank, Law No. 7558, at art. 2(a), available at: http://www. bccr.fi.cr/bccr home page/legal framework/laws/Organic Law BCCR.pdf. 
nomic activities" by granting "adequate and timely credit for increasing production, promoting productivity and efficiency, and seeking improvements in producers' technical capacities" to local financial institutions (art. 110.a, art. 110.b and art. 108, respectively).

Along similar lines, the law authorises the Bank to "buy, sell and maintain, as an investment, or as open market operations, first-class bonds and transferrable securities" with the Bank's Board determining the "kind of transferrable securities for the operations" as well as "buy and sell securities in the banking and stock markets" (art. 52(c) and 52(f) respectively). Thus, Costa Rica's central bank law clearly allows private asset purchases to play a key role in the country's monetary policy - if its policymakers so choose.

Monetary unions play a special role in empowering their central banks to purchase private sector assets. The Eastern Caribbean Central Bank Law allows accords the Bank with hands-on powers to acquire assets in member states like St. Vincent and the Grenadines. Specifically, the Law allows the Bank to "actively promote through means consistent with its other objectives [regulate availability of money and credit, monetary stability] the economic development of the territories of the Participating Governments" (art. 4.4). ${ }^{26}$ The Bank seemingly mixes the functions a central bank and development bank, "financing economic development of the territories of Participating Governments" (art. 42.e). The Bank may even "subscribe to, hold, and sell shares of a corporation organized with the approval or under the authority of the Participating Governments" albeit only for financing activities (art. 42.2). Yet, the law prohibits active - rather than passive - ownership by "engag[ing] in trade or participat[ing] directly or indirectly in the ownership of any financial, agricultural, commercial, industrial, or other enterprises" (art. 43).

The Bank of Central African States (BEAC) plays a radically different role for countries like Cameroon. The Bank just "issues the money of the Monetary Union and guarantees its stability. Without prejudice to this objective, the Bank supports the general economic policies of the Member States of this Union and these present laws" (art. 1). ${ }^{27}$ None of the Law's specific objectives hint at private asset

\footnotetext{
${ }^{26}$ Eastern Caribbean Central Bank Agreement Act, available at: http://www.eccb-centralbank. org/PDF/bank agreement1983.pdf, at article 4(4).

${ }^{27}$ Statutes of the Bank of Central African States, available at: https://www.beac.int/download/ statuts-02102010.pdf.
} 
purchases as part of such support to "general economic policies." ${ }^{28}$ Only one provision hints at the use of these purchases, authorising the use of foreign reserves to be "employed in market operations to buy, sell, lend, or borrow negotiable debt instruments denominated in foreign currency and issued by the government, private or public issuers, or international financial institutions having a rating equivalent to a AA from a rating agency or benefiting from a state guarantee from one of the countries named above or appearing on the official Government of the Central Bank list or belonging to the euro zone, in applying the directives fixed by the Monetary Policy Committee" (underlying ours, ibid, art. 11.1).

Countries like Malta occupy a special place in such currency/banking zones. They support the general objectives of the zone's central bank, in this case as the Law's subsidiary objective to "support the general economic policies in the [European] Union" (art. 4). ${ }^{29}$ The European Central Bank has its own law, objectives and rules. Yet, the Bank of Malta - as a member of the banking union - has its own rules which must conform to those of the Union. Within its division of competencies, the Law provides for the "subscription to, purchasing, selling, discounting or rediscounting equity, debt or other financial instruments as may be approved by the Board" only for "the satisfaction of debts due to it" and as long the Bank sells them "at the earliest suitable moment" (arts. 17(a) and 17(c) respectively). In other words, the Maltese central bank only takes on private assets as the result of unwanted circumstances, denying them any role in the conduct of monetary policy on the island. ${ }^{30}$

The fifth way that central bank law provides for investment, growth and thus potentially private asset purchases comes from omnibus exhortations to promote the national interest. Switzerland's law aims at "serving the interests of the country as a whole," while "in so doing, it shall take due account of economic development" (art. 5). ${ }^{31}$ The law gives the Swiss Central Bank the right to "buy and sell, in the financial markets, Swiss franc or foreign currency denominated receivables and securities" (art. 9.c). Just like in the other cases, Malaysia's law envisions achieving output goals through (rather than in addition to) price stability.

${ }^{28}$ These objectives include defining monetary and exchange rate policies, issuing money, managing foreign reserves, regulating payment systems and promoting financial stability.

${ }^{29}$ Central Bank of Malta Act (Cap. 204) at art. 4, available at: http://www.justiceservices.gov.mt/ DownloadDocument.aspx?app=lom\&itemid $=8713 \& \mathrm{l}=1$.

${ }^{30}$ We only state the facts. We do not try to explain here the reasons for these restrictions (which lets the ECB in Frankfort buy private assets but not Malta's central bank as an ECB member).

${ }^{31}$ Federal Act on the Swiss National Bank 951.11 at art. 5, available at https://www.admin.ch/opc/ en/classified-compilation/20021117/index.html. 
Yet, its central bank law represents one example of appealing to "the national interest" (art. 5.4). ${ }^{32}$ Combined with the vesting of "powers necessary, incidental or ancillary to give effect to its objects" its law seems to give a wide berth to private asset purchases -- or indeed any other policy (art. 5.3). As if to remove any doubt, article 26 authorises the Bank to "undertake such other financial transactions involving currencies, securities, precious metals or other commodities or financial instruments as approved by the Monetary Policy Committee" (art. 26.e). The Bank may even "establish a body corporate or acquire or hold shares of a body corporate, create a separate legal body for the purchases of [promoting financial stability." ${ }^{33}$ Yet, like most of its peers, the Act authorises the Bank to "purchase, sell, repurchase lend or borrow currencies, securities, gold..." while simultaneously prohibiting "the purchase of shares of any corporation" (arts. 75(d) and 76 (b) respectively).

The last group of countries consist of those where the law gives little if any weight to investment, growth and development. Uganda's law lists, as a last $11^{\text {th }}$ objective, "where appropriate" to "participate in the economic growth and development programmes" (chap. 51). ${ }^{34}$ In this vein, the Bank may "with the approval of the Minister and subject to [restrictions], subscribe to, hold and sell shares of any corporation or company established for the purpose of facilitating the financing of economic development" (art. 29.2.d). Yet, the law forbids the Bank to "engage in trade or otherwise have a direct interest in any commercial, agricultural, industrial, or any other undertaking" except when collected as part of a debt owed to the Bank and disposed of as soon as "reasonably practicable" (art. 29.3.a). With more details, the law forbids the Bank from the "purchase the shares of any body corporate or incorporate, including the shares of any financial institution" or "grant loans upon the security of shares" (art. 29(3)b and c).

Countries that engaged in private sector asset purchases after the global economic crisis tended to bend rules inadequately written for this purpose. For the EU, the Decision establishing the Corporate Sector Purchase Programme pinned

\footnotetext{
${ }^{32}$ Central Bank of Malaysia Act 2009, at article 5(4). available at: http://www.bnm.gov.my/documents/act/en cba.pdf. The Act, as if to ensure we heard it, repeats this objective in article 22 , as "in promoting monetary stability, the Bank shall pursue a monetary policy which serves the interests of the country with the primary objective of maintaining price stability giving due regard to the developments in the economy." Id at art. 22.

${ }^{33} \mathrm{Id}$ at article 48(c) - the provision makes reference to article 32, which refers to buying securities (usually of financial entities) to ensure financial stability. We replace that text to make this text more readable.

${ }^{34}$ The Bank of Uganda Act at Chap 51, available at: https://www.bou.or.ug/bou/bou-downloads/ acts/bou_act/BoUAct2000.pdf.
} 
its "constitutional" basis on the Treaty provision allowing the European Central Bank's governors "to define and implement the monetary policy of the Union" as well as the authority to "implement monetary policy in accordance with the guidelines and decisions laid down by the [ECB's] Governing Council", "to define and implement the monetary policy of the Union" (EU Treaty at art. 127.2 point 1).$^{35}$ On the positive side, the legal instrument the ECB relied on to buy private sector assets contained legal provisions no more specific or concrete than those in the countries we reviewed. On the negative side, these rules hardly give the central bank a clear mandate to engage in such purchases (a fact challenged by the German Constitutional Court as we will see later). If all academics agree about one thing from the Global Financial Crisis, they agree that well-defined, clear and sufficiently detailed rules should govern the central bank (and broader governmental) ability to buy private sector assets before the crisis appears. ${ }^{36}$

\section{Legal Prohibitions from Acting as a Funder of Last Resort}

Since the global economic crisis, many countries have considered using central bank purchases of private assets to prop up asset values - in effect making central banks funders of last resort in places like Russia (Farchy, 2014). In places like the UK, central bank rules increasingly allow central banks to hold private sector securities as collateral against bank loans - making the central bank still the final funder (Wallace, 2015; Goldfarb and Whittall, 2016). Sceptics like Nelson (2016) pejoratively refers to these purchases as get rich quick schemes. Yet, more central banks use "outright purchases" as an instrument of stabilization - rather than simply trying to influence money and credit through the banking system. Unlike typical lending, the Bank may share in residual risks/rewards of their collateral/assets. Such purchases make these banks funders-of-last-resort rather than lenders of last resort - as these purchases keep money flowing to productive enterprises in the same way any investment would.

Few countries have the de jure legal provisions in place to address crises using central bank purchases of private securities - making their de facto use both risky and unpredictable. Figure 5 shows the countries from our random sample whose central bank laws have provisions covering their banks' conduct during a crisis (or as a lender of last resort) as well as clear rules for engaging in private as-

${ }^{35}$ EU Treaty at art. 127.2 point 1. See also Protocol on the Statute of the European System of Central Banks and of the European Central Bank, available at: https://www.ecb.europa.eu/ecb/pdf/ orga/escbstatutes en.pdf. at article 12.1 para 2, 3.1 and

${ }^{36}$ See Rasmussen and Skeel (2016) for a restatement of this same idea. 
set purchases and the independence needed to act when government can not. Burundi, for example, may purchase assets of any kind, and indeed hold collateral from banks for their loans (art. 10). Yet, nothing in the law talks specifically about a lender of last resort function (even if the bank's purchase and sales powers give the bank such de facto power). Poland's central bank law forbids the bank from holding private securities and has no special section dealing with either financial emergencies (and thus a lender of last resort function) or its independence (art. 30). Elle's (2013) poorly done statistical analysis of the Bank of the Central African States (BEAC), finding that the Bank's finance to government and banks did more harm than good to investment and wealth creation led to the same conclusion - the central bank should fund productive business directly.

Figure 5: Only About $25 \%$ of Central Banks Have a Basis for Using Private Securities Purchases as a Last Resort

\begin{tabular}{lccccccccccc}
\hline Country & LLR & PC & I & Country & LLR & PC & I & Country & LLR & PC & I \\
\hline Jamaica & 0 & 1 & 0 & Argentina & 0 & 0 & 0 & Guatemala & 1 & 0 & 0 \\
\hline Haiti & 0 & 1 & 0 & Ecuador & 0 & 0 & 0 & Cameroon & $0^{* *}$ & 0 & 0 \\
\hline Poland & 1 & 0 & 0 & Oman & $1^{* *}$ & $0^{*}$ & 1 & Madagascar & 1 & $1^{*}$ & 0 \\
\hline Japan & 1 & 0 & 1 & Malaysia & 1 & 0 & 0 & St. Vincent & 1 & 1 & 0 \\
\hline Malta & 1 & 0 & 1 & Switzerland & 1 & 1 & 1 & Switzerland & 0 & 1 & 1 \\
\hdashline Uganda & 0 & 0 & 0 & Costa Rica & 1 & 0 & 0 & Turkmen & 0 & 0 & 0 \\
\hline Mauritania & 1 & 1 & 1 & Burundi & 0 & $0^{*}$ & 1 & Myanmar & 1 & 0 & 0 \\
\hline Mozambique & 0 & 0 & 0 & Poland & $0^{* *}$ & 0 & 0 & Philippines & 1 & 0 & 1 \\
\hline Iraq & 1 & $0^{*}$ & 1 & & & & & & & \\
\hline
\end{tabular}

$\mathrm{LLR}=$ lender last resort

$\mathrm{PC}=$ explicit authorisation for private collateral

I=independent

* Board has unlimited power to decide what securities - but private not mentioned specifically ${ }^{* *}=$ for national emergency... not specifically financial crisis

Mauritania (surprisingly) has a well thought-out stabilisation policy which explicitly allows for the kinds of policies the EU, US and UK pursuits under questionable legal authority. Mauritania's central bank law sets up a two-tier authorisation for buying assets. The Bank may serve as lender of last resort to banks under "exceptional circumstances" (art. 67). In a "grave financial crisis" or when "there does not exist any other way to avoid irreversible damage to the stability of the financial system," the Bank can receive collateral from "the public" -- presumably legal and natural persons (art. 68). The Law mentions "other counterparties" in contrast to "banks and financial establishments" in several places - which we interpret as private sector parties (art. 43). The Law also places such a premium 
on the Bank's independence that the drafters thought it prudent to demand that, "the independence of the Bank should be respected at all times and no person or entity should seek to influence the members of deciding bodies or agents of the Bank in the execution of their functions or interfere in the Bank's activities" (art. 3). The source of the Bank's protections of independence came about from an ordinance from the Military Council for Justice and Democracy - and military governments bad reputations for respecting the independence of executive bodies. Nevertheless, the words on paper look like everything a central bank like the Federal Reserve might need in a crisis.

Oman's law exemplifies most countries' approach to allowing funder of last resort asset purchases. Oman's central bank would deal with crises and situations requiring a lender/funder of last resort as a "national emergency" using "emergency provisions" (art. 19). Any discretionary activities conducted in such a situation should be "referred to the Board of Governors for ratification or modification at a special meeting."

Switzerland's law provides a far worse basis for establishing the basis for funder of last resort functions. The confederation's law highlights the Bank's role in protecting the stability of the financial system in a) requiring other parties to provide information, b) delivering that information to the Swiss Financial Market Supervisory Authority, c) letting these parties know about the information the Bank gave, and d) telling the Supervisory Authority the final outcome of its "information procurement" (art. 16(a)-16(d) respectively). Like most, the law only indirectly describes the Bank's authority to buy private sector securities, by letting it "buy and sell, in financial markets, Swiss franc and foreign currency denominated receivables and securities" and "enter into credit transactions with... other financial market participations [other than banks]" (ibid, art. 9(b) and 9(e) respectively). Poland's law gives its People's Bank a similar role of "provid[ing] the Committee for Financial Stability data and information... analyses, studies and opinions on the assessment of the systemic risk, financial stability and macroeconomic imbalances" (art. 30).

The two regional central banks in our random survey hold the clearest authorisations for making direct investments in productive private (or public) sector companies. The Central African States' Bank (BEAC) hints at its role in private securities markets by authorising the use of foreign reserves to be "employed in market operations to buy, sell, lend, or borrow negotiable debt instruments denominated in foreign currency and issued by the government, private or public issuers, or international financial institutions having a rating equivalent to a $\mathrm{AA}$ from a rating agency or benefiting from a state guarantee from one of the coun- 
tries named above or appearing on the official Government of the Central Bank list or belonging to the euro zone, in applying the directives fixed by the Monetary Policy Committee" (italics ours, art. 11.1). Unlike in the Central African Union, the Eastern Caribbean Central Bank Law specifically allows the Bank to "actively promote through means consistent with its other objectives [regulate availability of money and credit, monetary stability] the economic development of the territories of the Participating Governments" (art. 4.4). Mixing the functions a central bank and development bank, the Bank can furthermore engage in the "financing economic development of the territories of Participating Governments" (art. 42.e). The Bank may even "subscribe to, hold, and sell shares of a corporation organized with the approval or under the authority of the Participating Governments" albeit only for financing activities (art. 42.2). The law has the prohibition against "engag[ing] in trade or participat[ing] directly or indirectly in the ownership of any financial, agricultural, commercial, industrial, or other enterprises" (art. 43).

\section{Figure 6: Private Asset Purchases and the Costs of Incomplete Central Bank Law}

In hindsight, central banks responding to the financial crisis in a zero-interest environment would have responded better to the crisis with laws that allowed them to use private asset purchases more fully. Posner - in his analysis of the Fed - identified the following problems:

- act more cautiously than otherwise (p. 1)

- avoid accountability by blaming failures on the absence of law (p. 1)

- excessively structured transactions (p.2)

- fragmented authority and action with the Treasury, FDIC and SEC (p.2)

- shareholder litigation costs and fines (p.2)

- restrictions on fiscal activities

- requirements for full collateralisation and repayment.

- can value assets better than private actors - and see long-term value.

Source: Posner (2016).

Missing rules about private sector asset purchases in most of these central bank laws potentially impose significant costs on these central banks. Figure 6 shows many of the costs identified by scholars during the recent financial crisis to the US Federal Reserve Bank and to a lesser extent the European Central Bank. By some accounts, the Federal Reserve used legal machinations the US often exemplifies, in order to purchase securities. According to one account, the Fed created - and subsequently lent to -- five separate Delaware limited liability companies: Maiden Lane LLCs I, II, and III, Commercial Paper Funding Facility LLC 
(CPFF), and Term Auction Lending Facility LLC (TALF) in order to buy up securities (Koning, 2011). The Fed made these special purpose vehicles to get around the unclear authority in article 13 (which we previously discussed). Developing country banks may not be able/willing to create the special purpose vehicles needed to get around their laws like the US did.

The EU authorisation to buy private sector assets represents a wrong way to design such a programme. The now ended securities market programme gave the ECB the right to buy private sector securities. ${ }^{37}$ These securities had to come from a list of eligible assets, categorized as tier 1 and tier $2 .{ }^{38}$ Figure 7 and 8 show some salient securities from among the 2,370 securities listed for private and public sector companies only. Basically, the decision told the central bank which securities it could - and could not - purchase. Unlike the Outright Purchases Programme, the ECB adopted the Securities Market Programme "in view of the current exceptional circumstances in financial markets, characterized by severe

Figure 7: Is Treating the Central Bank Like an Idiot Such a Good Idea?

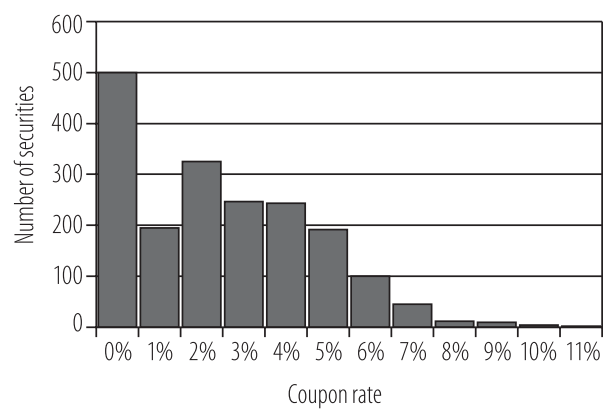

The figure shows the number of securities on the list of authorised securities to purchase and their corresponding coupon rates. Most have a coupon of zero -- yet the macroeconomic pay-off should concern central bankers far more than the nominal pay-off.

Source: ECB (2000).
Figure 8: Most Securities Not Discounted Very Much

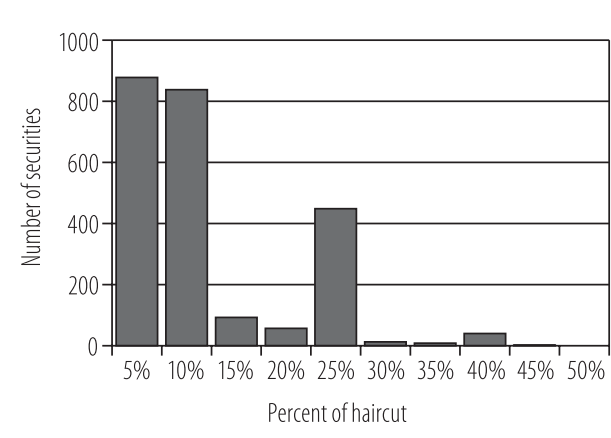

The figure shows the number of securities on the ECB's list along with the discount in the market value of these securites (something the ECB calls a "haircut").

Source: ECB (2000).

${ }^{37}$ Decision of the European Central Bank of 14 May 2010 Establishing a Securities Markets Programme (ECB/2010/5), available at: https://www.ecb.europa.eu/ecb/legal/pdf/en dec 20105 f sign.pdf?d69f741524fa86e19f437bc9177292d3 at art. 2.

${ }^{38}$ European Central Bank Guideline of the European Central Bank of 31 August 2000 on Monetary Policy Instruments and Procedures of the Eurosystem (ECB/2000/7), 2000, available at: https://www.ecb.europa.eu/ecb/legal/pdf/01_a en ecb 2000 7.pdf at Annex I, Chapter 6. 
tensions in certain market segments which are hampering the monetary policy transmission mechanism and thereby the effective conduct of monetary policy oriented towards price stability in the medium term." ${ }^{39}$ Figure 9 shows some of the private and less than private sector companies authorized on the list.

Figure 9: What Makes ECB Private Asset Investors Smarter than their Russian, Argentine and Yankee Counterparts?

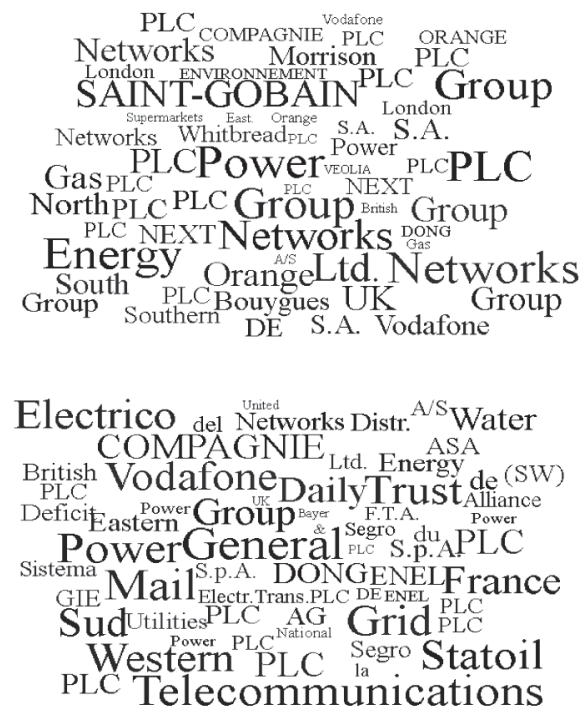

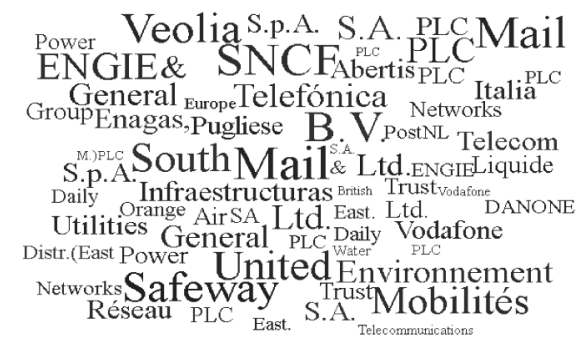

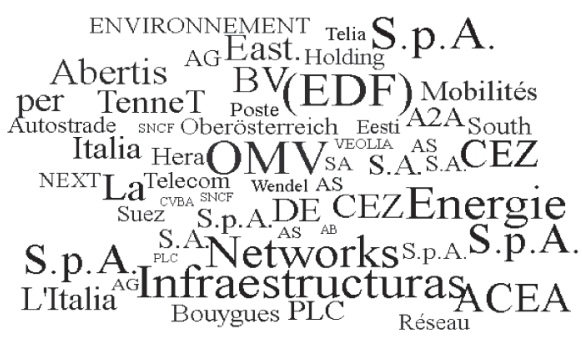

The word cloud shows examples of the over 5,000 companies and entities on the list of organisations authorized by the ECB for support. Why should lawmakers decide which securities central bankers buy tactically?

Source: ECB (2000).

The EU's and ECB's piecemeal approach to private securities purchases rulemaking has made even understanding - much less using - private asset purchase programmes exceedingly difficult. The ECB's main operational Guideline only contains mentions of outright transactions in passing. ${ }^{40} \mathrm{~A}$ technical Annex to a

\footnotetext{
${ }^{39}$ Decision of the European Central Bank of 14 May 2010 Establishing a Securities Markets Programme (ECB/2010/5), recital 2, available at https://www.ecb.europa.eu/ecb/legal/pdf/en dec 20105 f sign.pdf?d69f741524fa86e19f437bc9177292d3.

${ }^{40}$ Guideline (Eu) 2015/510 of the European Central Bank of 19 December 2014 on the Implementation of the Eurosystem Monetary Policy Framework (ECB/2014/60) (recast), available at: https://www.ecb.europa.eu/ecb/legal/pdf/oj_jol_2015 091_r_0002 en txt.pdf.
} 
press release contains much of the official wording for the programme. ${ }^{41}$ Other ad-hoc decisions and guidelines govern the treatment of collateral, asset backed securities, covered bonds and corporate bonds respectively. As Figure 10 shows, the regulate-as-you-go approach adopted by the ECB probably led to delays in the use of unconventional monetary policies related to private asset purchases which dulled the effective of these policies. The ECB's experience suggests that clear rules governing the ECB's use of asset purchases might have helped the Bank respond to the crisis promptly. Having clear authorisations in place similar to the ECB's might save other central banks the expense and delay experienced by the European economies.

Figure 10: Could Corporate Asset Purchase Regulations Have Helped the ECB Respond Faster/Better to the Crisis?

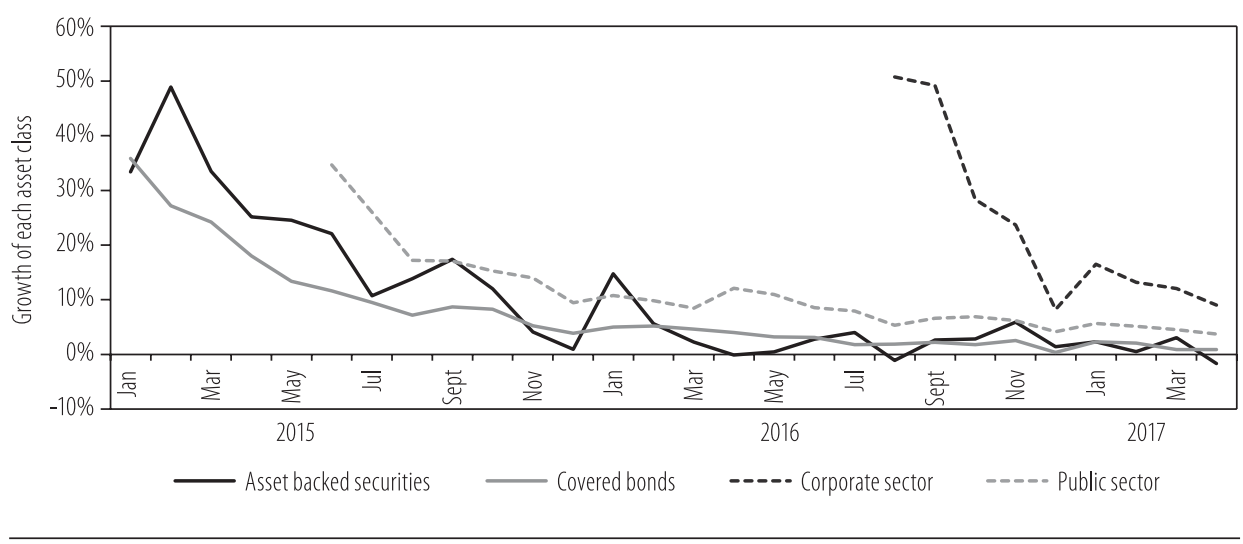

Source: ECB at History of cumulative purchases under the APP (2017).

As its part US Fed's experience shows what not to do. Ignoring the democratic or oversight arguments involved, we could not find any rigorous study showing that the Fed abused or even used its asset purchase powers incompetently or ineffectively. ${ }^{42}$ Many forgot about the conditions half a century ago which led Congress to give the Fed the power to fund companies directly - because banks would not - as Sablik (2013) describes. Figure 11 summarises the changes to the Federal Reserve Act and related legislation governing the Fed's use of asset purchases as a

${ }^{41}$ Press Release: ECB announces expanded asset purchase programme - Technical Annex ECB Announces Operational Modalities of the Expanded Asset Purchase Programme, 22 January, 2015, available at: https://www.ecb.europa.eu/press/pr/date/2015/html/pr150122 1.en.html.

${ }^{42}$ For one more official assessment, the Office of the Inspector General Report from 2010 fails to highlight any problem with the use of the Fed's Article 13(3) powers (which we describe throughout this paper). 
means to supporting asset markets. US rules have gone toward restricting private securities purchases. Most of these rules require the obvious - such as the admonition that the "Federal reserve bank shall obtain evidence that such individual, partnership, or corporation is unable to secure adequate credit accommodations from other banking institutions." ${ }^{43}$ Even among academics like Calomiris and others (2017), most favour putting in place rules dictating what the central bank should do in such exigencies. Yet, these rules seek to limit powers which the Fed has not demonstrably abused or used to limited effect. Proposals to limit the Fed's asset purchase powers - like those used to limit other central banks' powers - present solutions to unproven problems.

\title{
Figure 11: The US Federal Reserve: How Not to Amend a Central Bank Law
}

\begin{abstract}
Every rigorous analysis of Fed policy during the Global Financial Crisis we've seen has claimed that the Fed successfully used its powers in article 13(3) to buy particular assets and thus stave off further crisis. Yet, mob rule has resulted in several new or proposed laws which would hinder this ability. The Dodd-Frank Act at sec. 1101 prevents loans to single institutions (rather than as a broad sectoral or economy-wide programme as well as non-bank loans -- unless approved by the Treasury Secretary). The Act also places severe restrictions on lending to non-banks. A Financial Stability Improvement Act (sub-title $\mathrm{H})$ takes away discretionary authority to extend loans or make purchases - and vests such authority in a committee (the Board of Governors). The Fed Oversight Reform and Modernization Act prevents the Fed from taking equity as collateral (sec 11) and allows lending only to solvent companies.... in effect providing an umbrella only on sunny days. The Act requires the Fed to adopt nominal GDP targeting - something we advocate. Yet, that law (and the others) remove the Fed's ability to hit those targets by removing its ability to affect GDP at the firm level. Emerging markets should not look to US law to decide how to reform their central banks. ${ }^{44}$
\end{abstract}

Even if detractors have problems with central banks' direct purchase of securities, few could argue with the need to develop collateral and repurchase markets in most developing countries. Numerous laws accept the role of such funding to promote the creation of collateral. Jamaica's central law, for example, allows that country's central bank to "with the approval of the Minister grant loans and advanced for fixed periods to, or subscribe to, hold and sell the shares of any corporation which with the approval of or under the authority of the Government, is established for the purpose of promoting the development of a money market

\footnotetext{
${ }^{43}$ H.R.3996 - Financial Stability Improvement Act of 2009, at sub-title H, available at: https:// www.congress.gov/bill/111th-congress/house-bill/3996/text.

${ }^{44}$ All 6 of the sub-provisions in the section go against the analysis we have reviewed in this paper (namely the empirical results discovered in the crisis).
} 
or securities market in Jamaica, or of improving the financial machinery for the financing of economic development" (art. 23.j). At first glance, this law might seem to authorise state-owned or managed enterprises to take credits from the central bank. Yet, the complexity of the provision opens the door for the Bank's authority to lend, a tool in promoting the creation of money/securities markets rather than simply funding politically connected friends. And what better way to promote such development than through the creation of securities which can be lent, borrowed and otherwise used as collateral? ${ }^{45}$

\section{Wrapping Rules in a Statutory Mandate for Nominal GDP Targeting}

How to endow central banks with a simple mandate to buy private assets and do anything else needed to promote stabilization and growth? Despite calls for nominal GDP targeting among economists, legal scholars have paid almost no attention to central bank rules as an important area of public law in its own right. Economists like Frankel (2012) recently generally favour nominal GDP targets - as they provide both discipline and flexibility. ${ }^{46}$ Authors like Hoelle and Peiris (2013) find that such rules would ensure a Pareto efficient outcome only if all countries adopted these rules simultaneously and if all economic actors wanted the same things. For authors like Csermely and Toth (2013), the technical issues involved in such targeting would rule out such policies.

The very limited data available suggests that nominal GDP targeting would perform better than the current approach targeting prices. The zero interest rate environment (and the attending monetary policy conducted in a liquidity trap) revived much interest nominal GDP targets. ${ }^{47}$ Bhandari and Frankel (2015) in particular look at a social loss function similar to the Taylor monetary rule - one which penalises deviations from optimal output and low inflation rates. They find, in the Indian context, that a nominal GDP target would have raised welfare more than price targets. They particularly find the price elasticity of output needed such that central banks would prefer a price target (of roughly 2.14). Extending

${ }^{45}$ To keep this paper brief, we must ignore the role that such asset purchases might have on the creation of the collateral that makes financial and securities markets work. Ferrari and his coauthors (2017) provide a statistical analysis of the role that ECB purchases played in deepening these markets.

${ }^{46}$ Some models - like Garin et al.'s (2015) -- do not provide such clear-cut answers.

${ }^{47}$ Nikolsko-Rzhevskyy (2015) provide a readable (and rightly caustic) analysis of using such a rule as legislative mandate. Not everyone, like Billi (2013), agrees and depending on the model parameters, nominal GDP targeting could result in worse performance at the zero lower bound (when an economy stays stuck in a liquidity trap). 
on their work, we calculate the price elasticity of GDP for all the jurisdictions for which the World Bank have data - repeating the same procedures used by Bhandari and Frankel. Figure 12 shows the percent of countries and the percent of years (from 2005 to 2015) where price elasticities of output rose high enough to make price targets worthwhile. As shown, their model would only choose a price target in about $10 \%$ of the cases. Figure 13 generalises these results - showing that, under reasonable assumptions, such nominal GDP targets generally outperform other types of monetary policy rules.

Figure 12: Price Targeting Better than Nominal GDP Targeting only $10 \%$ of the Time at Most

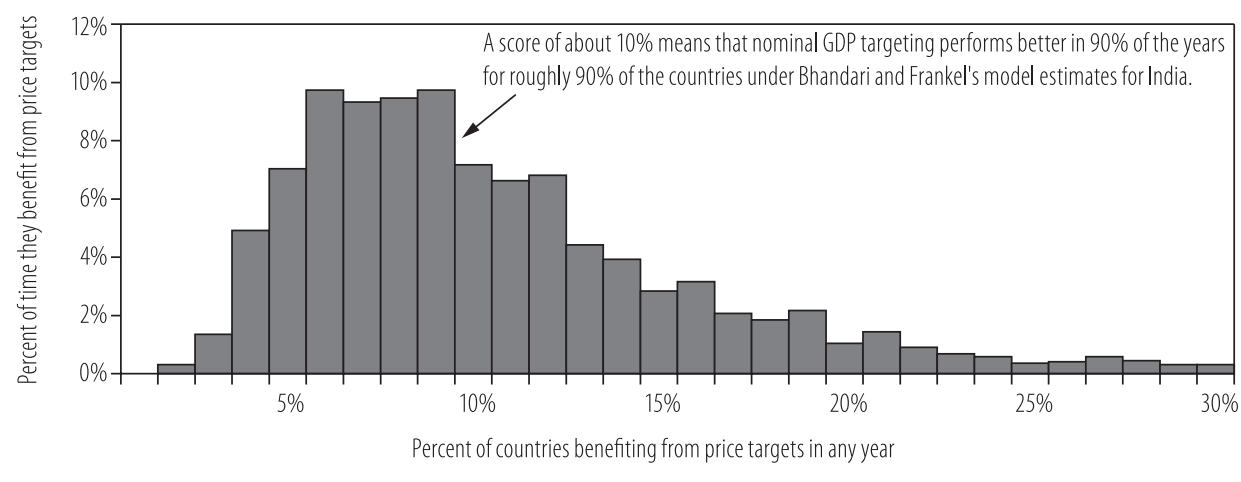

The figure shows the percent of years that countries benefits from a price, rather than a nominal GDP target. Thus, the greatest benefit these countries can hope for is that $10 \%$ ofcountries' monetary policy performs better $10 \%$ of the time from price targeting. The rest militates for nominal GDP targeting. We calculated these data by finding the inflation (GDP deflator) elasticity of aggregate supply (GDP) for each year from 2005 to 2015 for 180 countries. We flagged years where this elasticity exceeded Bhandari and Frankel's elasticity -- found for India - where a price target works better than a nominal GDP target. The data thus reflect proportion of "country years" (years for all countries) where nominal GDP targeting should perform worse. Naturally, $100 \%$ minus these data gives the extent to which nominal GDP targeting does better.

Sources: World Bank (for data) and Bhandari and Frankel (2015) for model and policy thresholds. 
Figure 13: Nominal GDP Targets Smooth Inflation and Output Gaps Best? (lower numbers $=$ "better")

\begin{tabular}{lccc}
\hline \multicolumn{1}{c}{ Model } & $\operatorname{var}(\pi)$ & $\operatorname{var}(\mathrm{y})$ & Welfare Loss \\
\hline Standard Taylor Rule & 4.12 & 2.32 & 2.95 \\
\hline Imperfect information Taylor Rule & 4.45 & 4.05 & 3.22 \\
\hline Nominal GDP Target & 3.60 & 3.12 & 2.60 \\
\hdashline Difference Rule & 4.38 & 3.73 & 3.16 \\
\hline
\end{tabular}

The Taylor Rule refers to a monetary policy whereby the central bank tries to minimise a weighted combination of price variability and output variability (or differences from some pre-defined desired level).

Source: Beckworth and Hendrickson (2015).

Such a mandate differs radically from the so-called Taylor Rule. Under such a rule, the central bank should - or must - follow a rule which requires the central bank to minimise an inflation gap and an output gap. As Labonte (2015) has observed, "the Taylor rule cannot make policy prescriptions at the zero lower bound-different combinations of deflation (falling prices) and output gaps would prescribe a negative federal funds rate under the Taylor rule, but that prescription would not be actionable because the federal funds rate is a market rate." As Bauducco et al. (2008) note, the central bank has superiour information which allows the institution to adjust to output and inflation gaps better than any Taylor Rule.

Existing central bank law shows the benefits of targeting nominal GDP as a central objective of a central bank's law. The Russian Central Bank law shows why a similar nominal GDP targeting rule provides far more transparency and accountability than a piece-meal approach. Figure 14 shows the various provisions in the 86 page law (the longest one we have seen in our sample). Article 2 of the law vesting federal ownership in any property owned by the Bank of Russia could exert a potentially market chilling effect on any private sector securities purchase programme. Numerous provisions allow for such provisions - under relatively ill-defined conditions and usually as a way of funding government entities. As we show in our previous review of central bank laws, both authorisations and prohibitions on buying private sector assets exist - usually leaving the decision up to the central bank's governing board. Such ad hoc authorisations to buy private sector securities provide a far worse basis for central bank policymaking than simply requiring the central bank to achieve a certain inflation/output mix under results-outcomes based legislation. 
Figure 14: Russian Central Bank Law as the Emblematic of Over-Legislating

\begin{tabular}{|c|c|}
\hline Article 8.5 & $\begin{array}{l}\text { The Bank of Russia shall not be entitled to participate in the capital or be a member of other commercial or non- } \\
\text { commercial organisations, if they do not provide support to the activities of the Bank of Russia and its institutions, } \\
\text { organisations and employees, except for the cases established by federal laws }\end{array}$ \\
\hline & [provisions above] shall not apply to Bank of Russia operations on the open market... \\
\hline Article 8.7 & $\begin{array}{l}\text { For the purpose of ensuring the rouble's stability, the Bank of Russia shall have the right to establish and (or) par- } \\
\text { ticipate in the capital of organisations engaged in the trust management of Bank of Russia assets, and also assets } \\
\text { transferred to their management by the Russian Federation, state corporations created by the Russian Federation } \\
\text { and other public legal entities or organisations, including foreign entities, for investment in the Russian Federation and } \\
\text { (or) foreign states. }\end{array}$ \\
\hline Article 26 & $\begin{array}{l}\text { The Bank of Russia shall disclose information about the transactions it conducts in trades organised by the stock } \\
\text { exchanges and (or) other organisers of trade on the securities market.... }\end{array}$ \\
\hline Article 39.2 & $\begin{array}{l}\text { Purchase and sale of other securities specified by the Board of Directors, provided that they are listed for organised } \\
\text { trades, as well as the conclusion of repo agreements with these securities. }\end{array}$ \\
\hline Articl & To buy and sell securities on the open market and also sell securities accepted as collateral for Bank of Russia loans \\
\hline Article 47.2 & $\begin{array}{l}\text { In the cases established by the decision of the Board of Directors, other valuables and also warranties and bank } \\
\text { guarantees may be used as security for Bank of Russia loans. A subsequent pledge of property held as collateral for } \\
\text { a credit institution's obligations to the Bank of Russia shall be allowed, if this is stipulated in an agreement between } \\
\text { the Bank of Russia and the credit institution. }\end{array}$ \\
\hline Art 76.1-12 & $\begin{array}{l}\text { Establishes a securities management company dependent on the central bank, supposedly for financial institutions' } \\
\text { "bankruptcy prevention." Yet, the law provides for no obvious arms-length relationship (and the central bank serves } \\
\text { as the only shareholder). }\end{array}$ \\
\hline
\end{tabular}

* The general tenor of the article does not favour the purchase or acceptance of such securities

Adding a nominal GDP target as a primary objective of a central bank law would also prevent much of the legal contortions central banks currently use to effect such transactions. The US Fed, for example, would not need to register a legal entity like "NGDP Targeting LLC" to engage in such purchases (Koning, 2011). Such an objective in Haiti's central bank law provides a more specific objective that "promoting the development of the national economy" (art. 2). Such an objective also improves upon a standard formulation in central bank laws like the Philippine's stating something to the effect that, "the primary objective of the [central bank] is to maintain price stability to a balanced and sustainable growth of the economy" (sec. 3). To repeat the formula, the Iraqi central bank law states that, "the primary objectives of the [central bank] shall be to achieve and maintain domestic price stability and foster and maintain a stable competitive marketbased financial system. Subject to these objectives, the [central bank] shall also promote sustainable growth, employment and prosperity in Iraq" (Annex A, sec. 3). Why leave such nominal GDP targets abstract and diffuse when central bank laws can incorporate them directly? 
The variety of institutional structures (and thus central bank laws) make the best way to introduce a nominal GDP target different, according to the context. Figure 15 shows possible ways of incorporating such a legal requirement in the different systems we reviewed in our random sample of central bank laws. The simplest approach consists of modifying existing objectives to read in the tight language of a nominal GDP target. In the case of a country like Poland (antithetical to output targeting), the objective could read, "The basic objective of the activity of NBP shall be to promote the growth of nominal GDP, namely growth in the real economy while maintaining price stability, while supporting the economic policy of the Government" (art. 3). As previously seen, lawmakers could consign output-based targets to subsidiary tasks and objectives. In Poland's case, such an objective might read "ensure the equitable, sustainable growth of nominal GDP, investing as necessary in productive assets while guaranteeing the stability of prices and foreign exchange." Nothing forbids the central bank from carrying out its other objectives as already enshrined in its central bank law.

\section{Figure 15: Legislative Approaches to Nominal GDP Targeting}

Lawmakers might consider the following legal drafting strategies for adding nominal GDP targeting to their central bank laws, only when central bank has guaranteed and proven independence and during times of crisis (as defined by the lawmakers).

1. Direct application. Adding nominal GDP growth as a primary (or if impossible) a secondary objective during an economic crisis for the purposes of stabilization. The legislature can decide whether to set up a limited account from which the central bank can conduct purchases.

2. Through government policy. For central bank laws requiring following government policies/rules, an executive degree could simply establish the nominal GDP target (and thus the authorisation to purchase private securities on an independent basis).

3. Definition of already existing objectives. When the central bank law already makes reference to economic objectives, to add the purchase of non-inflationary, GDP growth enhancing portfolio holdings in the short or longer run - rather than leaving it to a monetary policy committee to decide.

4. Lender of last resort and stabilisation rules. When the central bank law includes sections on the bank's role as lender of last resort and/or stabilization, explicitly allow for the purchase and holdings of private sector securities directly as a function of the bank.

5. Distribution rules for monetary unions. When a crisis affects several members of an economic union, either a separate treaty or negotiated executive level regulation could define the level of private asset purchases from each country and which shares the bank buys from which jurisdiction.

6. Relations with national development banks. The law would define conditions under which the Bank would transfer securities to the development bank (if existing) or operate a department as a developmental arm. 
Why would a nominal GDP target authorise a central bank to participate more directly in private sector securities markets (rather than through expanding bank credit)? The Bahamas central bank law provides an obvious example. The Bank's objectives require the Bank to "a) promote and maintain monetary stability and credit and balance of payments conditions conducive to the orderly development of the economy, b) in collaboration with the financial institutions, to promote and maintain adequate banking services and high standards of conduct and management therein, and c) to advise the Minister" (art. 5). Almost as an after-thought, the Law allows the Bank to buy company/corporate bonds at art. 29.1(d), securities at art. 29.1(e), or lend in general at art. 29.1(f). One could hardly imagine a situation where such purchases or loans aim primarily at maintaining monetary stability (as required by the Bank's objective). If buying private sector securities helps promote stabilisation and economic growth, law should quell public debate and let technocrats get on with allocating capital to its highest risk and externality adjusted, expected marginal returns. ${ }^{48}$

At the very least, the explicit mandate to maximise nominal long-term, risk-adjusted, nominal GDP would simplify central bank laws. In the previous sections, we reviewed the numerous cases where central bank laws repeated authorisations to buy securities (often related to the government). In a developing/emerging market context, other authors like Akhtar and colleagues (2009), have also found that central bank asset purchases should probably focus less on public debt/securities - and more on private sector securities. Putting authorisations for buying private sector securities in a subsequent section (like Malaysia's Part VI Chapter 1) only distracts attention away from the central bank's dual role in maximising real output (with optimal inflation). Japan's central bank law clearly absolves the central bank from any responsibly for development or output growth - something most "synthesis economists" would find bizarre. ${ }^{49}$

\footnotetext{
${ }^{48}$ Academics have found fashionable calls for more democracy in central bank asset purchases. Johnston and Pugh (2014) represent one of the most baleful examples of such writing. They object to the ECB's purchase of government bonds (a basic central bank tool of monetary policy) and call for greater open debate - without showing how such debate would led to better outcomes.

${ }^{49}$ Synthesis economists refer to most professional PhD economists educated after the 1970s integrating fiscal and monetary policies into a theory of output and inflation (Goodfriend and King, 1997).
} 


\section{Conclusions}

Central bank laws represent an under-researched part of public law. Such public law determines the central bank's ability to respond to economic crises, and its longer-term ability to help/hinder economic growth. In this paper, we look at the legal bases for central bank laws - and particularly the basis for buying private sector securities. Legislation - and even the constitution in a few cases - takes an adversarial position on such purchases, despite these central banks' wide-spread use of such purchases as anti-crisis measures. No theory on public law has dared to grapple with these kinds of kinds - and having some data on the issue represents a first step toward understanding such central bank law.

In this article, we show how laws can authorize central bank purchases of private sector securities - leaving questions about the economic or political desirability of such purchases to other papers. We show that most central bank laws do allow for these purchases - usually in the form of wider discretionary powers accorded to the central bank's main policymaking body. Yet, no law proactively encourages these purchases. Even in times of crisis, these central bank laws provide little clarification on these banks' powers and obligations - reflecting the lack of any over-arching jurisprudence on the subject. At the very least, a political discussion about nominal GDP targeting rules could start a broader discussion about jurisprudential traditions countries want to establish for this vital area of public law.

We identify different ways that countries' laws deal with central bank powers. Where legislation sets out the central bank's powers, legislators could directly add provisions giving the central bank the responsibility to grow GDP, and the power to influence such an outcome by engaging in activities like buying private sector securities. For countries, giving the executive broad powers over the central bank, such reform could come from the stroke of a president's pen. In cases where legislators could extend existing definitions and objectives, they may find adding provisions like nominal GDP targeting and private sector asset purchases more easily by just extending legal definitions related to stabilization policies. When monetary union treaties, rather than parliamentary acts or executive orders, set out these objectives -- rules describing the distribution of economic growth play as important a role as growth itself. Such public law issues then turn into questions of the international law governing the supra-national central bank. Scholars have yet to even think about these issues in-depth. 


\section{References}

1. Akhtar, S., Lorie, H. and Petersend, A. (2009). Effectiveness of Central Banks And Their Role In The Global Financial Crisis. Asian Development Bank Monograph. Available at: https://www.adb.org/sites/default/files/ publication/27504/central-bank-effectiveness.pdf.

2. Asso, P. F., Kahn, G. .A., and Leeson, R. (2010). The Taylor Rule and the Practice of Central Banking. Kansas City Federal Reserve Bank Research Working Paper 10-05. Available at: https://www.kansascityfed.org/publicat/ reswkpap/pdf/rwp10-05.pdf

3. Bauducco, S., Bulir, A. and Cihak, M. (2008). Taylor Rule Under Financial Instability, IMF Working Paper WP/08/18. Available at: https://www.imf.org/ external/pubs/ft/wp/2008/wp0818.pdf

4. Bhandari, P. and Frankel, J. (2015). Nominal GDP Targeting For Developing Countries. NBER Working Paper 20898. Available at: http://www.nber.org/ papers/w20898.pdf

5. Beckworth, D. and Hendrickson, J. (2015). Nominal GDP Targeting and the Taylor Rule on an Even Playing Field. Available at: http://people.wku.edu/ david.beckworth/taylor ngdp.pdf

6. Billi, R. (2013). A Note on Nominal GDP: Targeting and the Zero Lower Bound, Sveriges Riksbank Working Paper Series 270. Available at: http:// www.riksbank.se/Documents/Rapporter/Working papers/2016/rap wp270_160122_revised.pdf

7. Borio, C. and Zabai, A. (2016). Unconventional Monetary Policies: A ReAppraisal. BIS Working Papers No 570. Available at: http://www.bis.org/ publ/work570.pdf

8. Bossone, B., Fazi. T., and Wood, R. (2014). Helicopter money: The best policy to address high public debt and deflation, Vox 1 October. Available at: http://voxeu.org/article/helicopter-money-today-s-best-policy-option

9. Broaddus, A. and Goodfriend, M. (2000). What Assets Should the Federal Reserve Buy? Federal Reserve Bank of Richmond Annual Report. Available at: https://www.richmondfed.org/ /media/richmondfedorg/publications/ research/annual report/2000/pdf/article.pdf

10. Calomiris, C., Holtz-Eakin, D., Hubbard R. G., Meltzer, A., and and Scott, H. (2017). Establishing Credible Rules for Fed Emergency Lending. Available at: http://www.capmktsreg.org/wp-content/uploads/2017/02/JFEPPaper-LLR-statement-SSRN-version-Feb-1-2017.pdf

11. Csermely, A. and Toth, M. (2013). Nominal GDP Targeting: What Are Central Bankers Talking About? MNB Bulletin. Available at: https://www. mnb.hu/letoltes/csermely-toth.pdf 
12. Elle, S. (2013). The BEAC Central Bank and Wealth Creation in Cameroon Economy, International Journal of Innovation and Applied Studies 3(3). Available at: http://www.issr-journals.org/links/papers.php?journal=ijias\&a pplication $=$ pdf\&article=IJIAS-13-114-09

13. Emerson, C. (2010). The Illegal Actions of the Federal Reserve: An Analysis of How the Nation's Central Bank Has Acted Outside the Law in Responding to the Current Financial Crisis. William \& Mary Business Law Review 1(1). Available at: http://scholarship.law.wm.edu/cgi/viewcontent. cgi?article $=1004 \&$ context $=$ wmblr

14. Farchy, J. (2014). Russia's central bank to help companies refinance debts, Financial Times December 24. Available at: https://www.ft.com/ content/6ef85db6-8b6d-11e4-be89-00144feabdc0

15. Fawley, B. and Juvenal, L. (2012). Quantitative Easing: Lessons We've Learned. St. Louis Federal Reserve Bank's Regional Economist June. Available at: https://www.stlouisfed.org/ /media/Files/PDFs/publications/pub_assets/ pdf/re/2012/c/QE.pdf

16. Federal Reserve Act. (1913) Section 13. Powers of Federal Reserve Banks. Available at: https://www.federalreserve.gov/aboutthefed/section13.htm

17. Ferrari, M., Guagliano, C. Mazzacurati, J. (2017). Collateral scarcity premia in Euro area repo markets. ESMA Working Paper 1. Available at: https://www.esma.europa.eu/sites/default/files/library/esma_wp_1_2017 collateral scarcity premia in ea repo markets.pdf

18. Fettig, D. (2002). Lender of More Than Last Resort: Recalling Section 13(b) and the Years When the Federal Reserve Banks Opened Their Discount Windows to District Businesses in Times of Economic Stress. The Federal Reserve Bank of Minneapolis' Region Paper. Available at: https://www. minneapolisfed.org/publications/the-region/lender-of-more-than-last-resort

19. Frankel, J. (2012). The Death of Inflation Targeting. Vox, 19 June. Available at: http://voxeu.org/article/inflation-targeting-dead-long-live-nominal-gdptargeting

20. Gagnon, J., Raskin, M., Remache, J. and Sack, B. (2010). Large-Scale Asset Purchases by the Federal Reserve: Did They Work? Federal Reserve Bank of New York Staff Report no. 441. Available at: https://www.federalreserve.gov/ monetarypolicy/files/FOMC20100301memo01.pdf

21. Gambacorta, L.,, Hofmann, B. and Peersman, G. (2014). The Effectiveness of Unconventional Monetary Policy at the Zero Lower Bound: A CrossCountry Analysis. Journal of Money, Credit and Banking 46(4). Available at: http://users.ugent.be/ gpeersma/gert files/research/jmcb12119.pdf

22. Garin, J., Lester, R. and Sims, E. (2015). On the Desirability of Nominal GDP Targeting. CATO Working Paper 32/CMFA No. 7. Available at: https:// object.cato.org/sites/cato.org/files/pubs/pdf/working-paper-32.pdf 
23. Goldfarb, S. and Whittall, C. (2016). New Tool for Central Banks: Buying Corporate Bonds. Wall Street Journal Aug. 4. Available at: https:// www.wsj.com/articles/new-tool-for-central-banks-buying-corporatebonds-1470350276.

24. Goodfriend, M. and King, R. (1997). The New Neoclassical Synthesis and the Role of Monetary Policy. NBER Macroeconomics Annual 12.

25. Hobson, D. (2016). The Collateral Management Practices of Central Banks: The Case for Modernisation. Clearstream Working Paper. Available at: http://www.clearstream.com/blob/80032/485e200d9e2211552c9fad19dc3a fc25/coll-mgt-central-banks-data.pdf

26. Hoelle, M. and Peiris, U. (2013). On the Efficiency of Nominal GDP Targeting in a Large Open Economy. Krannert Working Paper Series, Paper No. 1273. Available at: https://www.aeaweb.org/conference/2014/retrieve. php?pdfid=132

27. IMF. (2016). Updates Central Bank Legislation Database. Available at: https://www.imf.org/en/News/Articles/2016/08/15/NA081516-IMF-updatescentral-bank-legislation-database

28. Johnson, E. (2016). VIII Revisions to the Federal Reserve's Emergency Lending Rules. Review of Banking \& Financial Law 35(10). Available at: https://www.bu.edu/rbfl/files/2016/10/Pages-from-Development-ArticlesFormatted-7.5.pdf

29. Johnston, A. and Pugh, T. (2014). The Law and Economics of Quantitative Easing. Sheffield Institute of Corporate and Commercial Law Working Paper Series. Available at: https://papers.ssrn.com/sol3/papers.cfm?abstract $\underline{\mathrm{id}=2463160}$

30. Joyce, M., Miles, D., Scott, A. and Vayanos, D. (2012). Quantitative Easing and Unconventional Monetary Policy - An Introduction. Economic Journal 122. Available at: http://qed.econ.queensu.ca/faculty/milne/870/QE\%20 and\%20unconventional\%20monetary\%20policy.pdf

31. Khan, A. (2017). Central Bank Legal Frameworks in the Aftermath of the Global Financial Crisis. IMF Working Paper WP/17/101. Available at: http:// www.imf.org/ /media/Files/Publications/WP/2017/wp17101.ashx

32. Koning, JP. (2011). The legal scope of Fed purchases. Available at: http:// worthwhile.typepad.com/worthwhile canadian initi/2011/11/the-legalscope-of-fed-purchases.html

33. Labonte, M. (2016). Federal Reserve: Emergency Lending, Congressional Research Service Report 7-5700. Available at: https://fas.org/sgp/crs/misc/ R44185.pdf

34. Labonte, M. (2015). Federal Reserve: Legislation in the 114th Congress, Congressional Research Service R44273. Available https://fas.org/sgp/crs/ misc/R44273.pdf 
35. Lane, T. (2015). Central Bank Operating Frameworks and Collateral Markets. Committee on the Global Financial System Markets Committee Papers No 53. Available at: http://www.bis.org/publ/cgfs53.pdf

36. Le Maux, L. and Scialom, L. (2013). Central Banks and Financial Stability: Rediscovering the Lender-of-Last-Resort Practice in a Finance Economy. Cambridge Journal of Economics 37(1). Available at: https://academic.oup. com/cje/article/37/1/1/1683052/Central-banks-and-financial-stability

37. Nelson, E. (2016). Central banks have hatched a get-rich-quick scheme for companies in an attempt to avoid a slowdown. Quartz, Aug 25. Available at: https://qz.com/765285/central-banks-have-hatched-a-get-rich-quickscheme-for-companies-in-an-attempt-to-avoid-a-slowdown/

38. Nikolsko-Rzhevskyy, A., Papell, D. and Prodan R. (2015). Policy Rule Legislation in Practice. Available at: https://papers.ssrn.com/sol3/papers. cfm?abstract id $=2697168$

39. Nyborg, K. (2015). Central Bank Collateral Frameworks. Available at: http:// www.stat.uchicago.edu/ mykland/ecoll art Feb2015 11 complete.pdf

40. Paries, M. and Kuhl, M. (2016). The Optimal Conduct of Central Bank Asset Purchases. ECB Working Paper Series 1973. Available at: https://www.ecb. europa.eu/pub/pdf/scpwps/ecbwp1973.en.pdf

41. Office of Inspector General, (2010), Board of Governors of the Federal Reserve System Office of Inspector General, The Federal Reserve's Section 13(3) Lending Facilities to Support Overall Market Liquidity: Function, Status, and Risk Management. Available at: https://oig.federalreserve.gov/ reports/FRS Lending Facilities Report final-11-23-10 web.pdf

42. Posner, E. (2016). What Legal Authority Does the Fed Need During a Financial Crisis? Coase-Sandor Working Paper Series in Law and Economics No. 741. Available at: http://chicagounbound.uchicago.edu/cgi/viewcontent. cgi?article $=2433 \&$ context $=$ law and economics

43. Rasmussen, R. and Skeel, D. (2016). Governmental Intervention in an Economic Crisis, University of Pennsylvania Journal of Business Law 19. Available at: http://www.ecgi.global/sites/default/files/working papers/ documents/345-2017.pdf

44. Sablik, T. (2013). Fed Credit Policy During the Great Depression, Federal Reserve Bank of Richmond Economic Brief EB13-03. Available at: https:// www.richmondfed.org/ /media/richmondfedorg/publications/research/ economic brief/2013/pdf/eb 13-03.pdf

45. Saravelos, G., Brehon, D., and Winkler, R. (2016). Helicopters 101: your guide to monetary financing. Deutsche Bank Special Report 15 April. Available at: https://www.db.com/newsroom_news/GDPBD00000292870. pdf 
46. Shill, G. (2015). Does the Fed Have the Legal Authority to Buy Equities? Available at: https://blog.supplysideliberal.com/post/114021461013/gregshill-does-the-fed-have-the-legal-authority

47. Tucker, P. (2014). The Lender of Last Resort and Modern Central Banking: Principles and Reconstruction. Bank for International Settlements Paper 79. Available at: http://www.bis.org/publ/bppdf/bispap79b rh.pdf

48. Wallace, T. (2015). Bank of England plans to accept equities as collateral from banks. UK Telegraph, 13 Jul. Available at: http://www.telegraph.co.uk/ finance/bank-of-england/11736422/Bank-of-England-to-accept-equities-ascollateral-from-banks.html

49. Weale, M. and Wieladek, T. (2014). What Are the Macroeconomic Effects of Asset Purchases? Bank of England Monetary Policy Committee Discussion Paper No. 42. Available at: http://www.bankofengland.co.uk/ monetarypolicy/Documents/externalmpc/extmpcpaper0042.pdf

50. Woodford, M. (2012). Methods of Policy Accommodation at the InterestRate Lower Bound. Federal Reserve Bank of Kansas City Symposium on The Changing Policy Landscape, Jackson Hole, Wyoming. Available at: http:// www.columbia.edu/ mw2230/JHole2012final.pdf 